\title{
- Significance of right ventricle function assessment and pulmonary vascular resistance after heart transplantation
}

\section{Jana Ljubas Maček*, Boško Skorić, Marijan Pašalić, Hrvoje Gašparović, Daniel Lovrić, Maja Čikeš, Jure Samardžić, Hrvoje Jurin, Ana Reschner, Davor Miličić}

University of Zagreb School of Medicine, University Hospital Centre Zagreb, Zagreb,

Croatia

\begin{abstract}
KEYWORDS: right ventricle, longitudinal function, heart transplantation, pulmonary vascular resistance, tricuspid annular plane systolic excursion.

CITATION: Cardiol Croat. 2017;12(9-10):365-366. | https://doi.org/10.15836/ccar2017.365

*ADDRESS FOR CORRESPONDENCE: Jana Ljubas Maček, Klinički bolnički centar Zagreb, Kišpatićeva 12, HR-10000 Zagreb, Croatia. / Phone: +385-98-577-707 / E-mail: janaljubas@yahoo.com

ORCID: Jana Ljubas Maček http://orcid.org/0000-0001-7171-2206 • Boško Skorić http://orcid.org/0000-0001-5979-2346 Marijan Pašalić http://orcid.org/0000-0002-3197-2190 • Hrvoje Gašparović http://orcid.org/0000-0002-2492-3702

Daniel Lovrić http://orcid.org/0000-0002-5052-6559 • Maja Čikeš http://orcid.org/0000-0002-4772-5549 Jure Samardžić http://orcid.org/0000-0002-9346-6402 • Hrvoje Jurin http://orcid.org/0000-0002-2599-553X Ana Reschner http://orcid.org/0000-0002-6723-6822 • Davor Miličić http://orcid.org/0000-0001-9101-1570

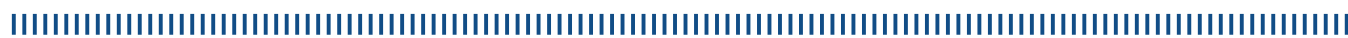
Introduction: To test the effect of pretransplant pulmonary vascular resistance (PVR) on posttransplant right ventricle (RV) size and function as well as to address the possible causes, except cardiotomy ${ }^{1}$, affecting the RV function and its recovery trend after heart transplantation ${ }^{2}$ (HTx). Also to compare invasive and echocardiographic RV function measurements and their impact on survival.

Patients and Methods: PreHTx right heart catheterization (RHC) as well as postHTx ECG, echo and RHC were performed in 84 adult heart transplant pts. RV longitudinal function was assessed by tricuspid annular plane systolic excursion (TAPSE). Data on PVR, transpulmonary gradient (TPG), RV stroke work index (RVSWI) as well as graft ischemic time (GIT), extracorporeal circulation time (ECCT) and time on mechanical ventilation were collected.
\end{abstract}

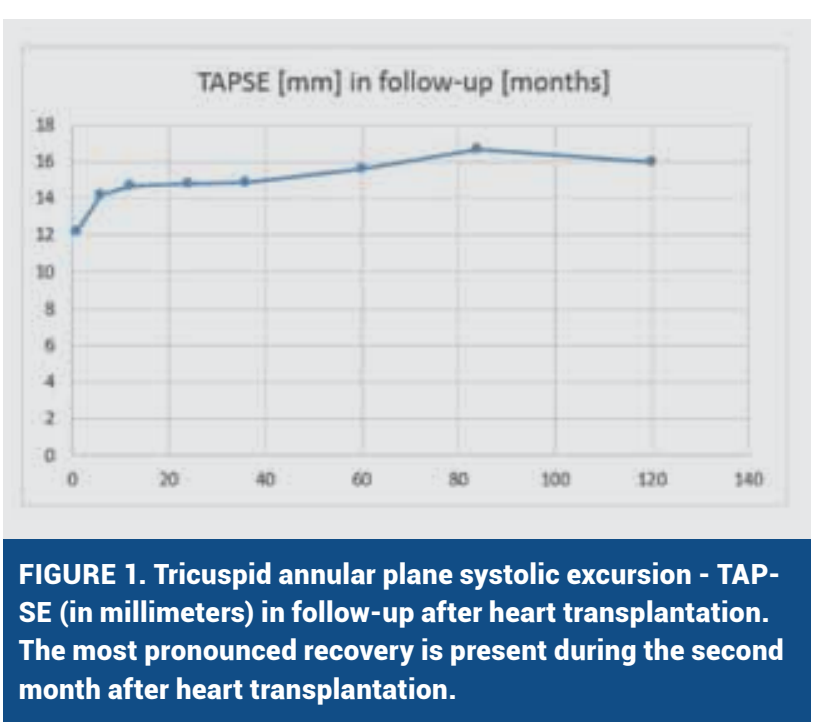

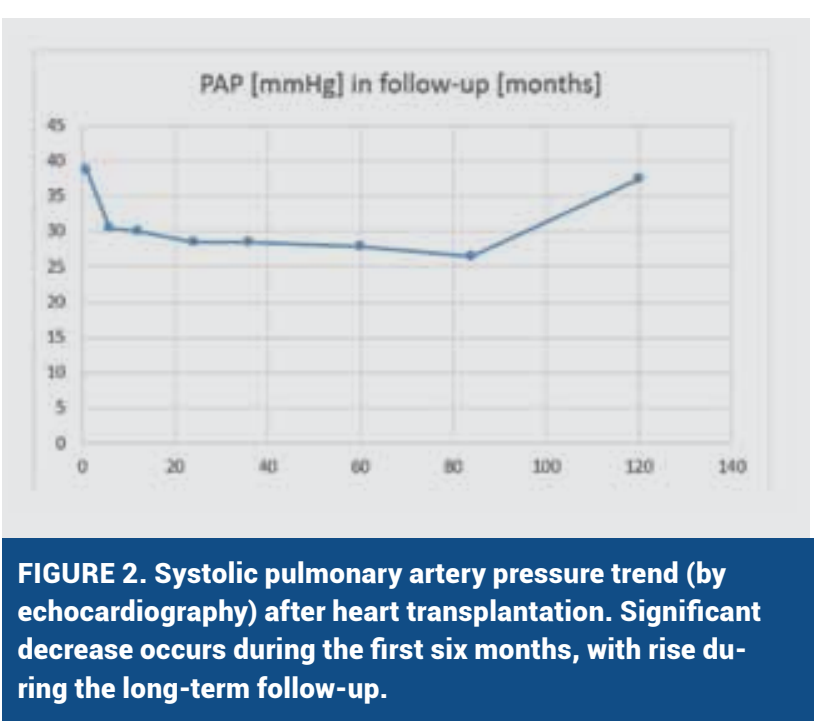

RECEIVED:

September 24, 2017

ACCEPTED:

September 26, 2017

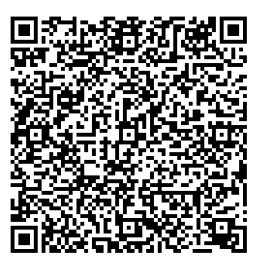

Results: The development of RBBB after HTx was not related with longer GIT or ECCT, and had no effect on posttransplant RV dilatation or function and survival. RV was dilated in $36 \%$ of pts in the 1st month after HTx with mean TAPSE $12 \pm 4 \mathrm{~mm}$, which increased to $16 \pm 4 \mathrm{~mm}$ during the 2nd month. $63 \%$ of pts had reduced initial TAPSE with further recovery in only $44 \%$ (Figure 1). Longer GIT, ECCT and duration of mechanical ventilation had no influence on TAPSE or on the development of acute RV failure. Postransplant RV function assessed both by TAPSE or RVSWI had no influence on survival. RVSWI was significantly reduced in early postHTx period $\left(5 \mathrm{gm}-\mathrm{m} / \mathrm{m}^{2}\right)$ but did not correlate with TAPSE. Pts with normal pretransplant PVR and TPG had similar posttransplant TAPSE and RVSWI in comparison to pts with reversibly increased PVR and TPG. PVR decreased for $43 \%$ after HTx (mean $203 \pm 102$ to $116 \pm 45$ dynes-sec-cm-5; $p<0.001$ ). Systolic pulmonary arterial pressure assessed by echo was mildly to moderately elevated in early postHTx period $(39 \pm 11 \mathrm{mmHg}$ ) with trend to normalization within the first 6 months after HTx (Figure 2). 
Conclusion: Posttransplant loss of the RV longitudinal systolic function was present in $60 \%$ of pts and recovered in almost half of them, but with no effect on patients' survival. Higher and reversibly elevated pretransplant PVR and TPG did not add to the more pronounced decrease in RV longitudinal function posttransplant. Interestingly, post-transplant RVSWI as an invasive measure of RV function did not correlate with TAPSE.

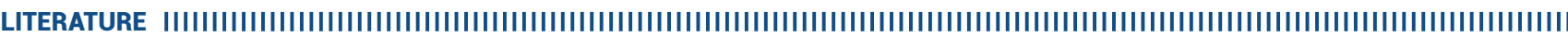
1. Raina A, Vaidya A, Gertz ZM, Susan Chambers, Forfia PR. Marked changes in right ventricular contractile pattern after cardiothoracic surgery: implications for post-surgical assessment of right ventricular function. J Heart Lung Transplant. 2013 Aug;32(8):777-83. https://doi.org/10.1016/j.healun.2013.05.004

2. Van Trigt P, Bittner HB, Kendall SW, Milano CA. Mechanisms of transplant right ventricular dysfunction. Ann Surg. 1995 Jun;221(6):666-75. PubMed: https://www.ncbi.nlm.nih.gov/pubmed/7794071 